Tạp chí Khoa học và Công nghệ biển T10 (2010). Số 4. Tr 39 - 49

\title{
SOFT CORALS (OCTOCORALLIA: ALCYONACEA) IN LY SON ISLANDS, THE CENTRAL OF VIETNAM
}

\author{
HOANG XUAN BEN
}

Viện Hải dương học

TATYANA N. DAUTOVA

Viện Hàn lâm Khoa học Nga

\begin{abstract}
Summary: Ly Son district belongs to Quangngai province including Dao Lon and Dao Be islands. They were located in central of Vietnam far $20 \mathrm{~km}$ from mainland. The environment in Ly Son is considered so different that compare with the ecological environment of near shore reefs of Vietnam. The reefs exist in the turbidity but calm waters. Especially, the reefs which located far from the mainland coast are studied less interested than offshore. The total 85 specimens were collected. The results of examination are recorded 60 taxa including 10 genera and 5 families in this area. Among these presents, two genera and 33 species are firstly recorded in comparison with the octocoral fauna of Vietnam which fauna has been the subject of several studies. The result showed that 14 species of Sinularia, 9 species of Lobophytum, 6 species of Sarcophyton genera are newly recorded in Vietnam. Meanwhile, only one new species belonging to the Hicksonella, Paralemnalia, Nephthea, Xenia genera is firstly recorded in Vietnam.
\end{abstract}

Key words: Octocorallia, soft corals, new records, South China Sea, Vietnam.

\section{INTRODUCTION}

The soft corals (Cnidaria: Octocorallia) have the ability to occupy the significant bottom areas belonging to the main components of the coral reef ecosystems of the tropics. The survey of the biodiversity in soft corals is needed for solving the important problem of the tropical marine ecosystems and contribution to predict the damaged and healthy coral reefs in the nearest future. The octocoral fauna of Vietnam has been the subject of several studies. An early collection of soft coral conducted by Hickson in 1919, resulted in the description of one new species Alcyonium krempfi in the central of Vietnam (Hickson, 1919). Subsequently, Stiasny determined 18 species of gorgonians listed for Southern of Vietnam. The author described two species Eunicella dawydoffi and Junceella bifurcata as the new species for science. In 1970 Tixier-Durivault listed 94 species of soft coral in Nha 
Trang bay and this scientific research was considered the most significant for taxonomy of soft coral in Vietnam. Later, Malyutin (1991) described two new species Sinularia mammifera and S. laminilobata in Con Dao islands and Dautova \& Savinkin (2009) determined two species Eleutherobia nezdoliyi and Sinularia arctium in Nha Trang bay.

Ly Son district belongs to Quangngai province including Dao Lon and Dao Be islands far $20 \mathrm{~km}$ from mainland. The status of coral reef in Ly Son islands have not almost studied even that include the biodiversity of coral reef. This result is firstly proved to the science that concern with the biodiversity of soft coral in Ly Son islands. By the way, the species composition of soft corals in Ly Son may be of the great interest in comparison with the data on the coastal soft corals of Vietnam.

\section{MATERIALS AND METHODS}

Table 1: The stations and positions where the samples were collected in Ly Son islands (showed in figure 1).

\begin{tabular}{|c|l|l|}
\hline Stations & latitude & Longitude \\
\hline I & $15^{0} 23^{\prime} 50^{\prime \prime}$ & $109^{0} 06^{\prime} 33^{\prime \prime}$ \\
\hline II & $15^{0} 23^{\prime} 05^{\prime \prime}$ & $109^{0} 04^{\prime} 59^{\prime \prime}$ \\
\hline III & $15^{0} 23^{\prime} 51^{\prime \prime}$ & $109^{0} 08^{\prime} 16^{\prime \prime}$ \\
\hline IV & $15^{0} 25^{\prime} 39^{\prime \prime}$ & $109^{0} 05^{\prime} 17^{\prime}$ \\
\hline
\end{tabular}

The samples of the colonial Octocorallia were collected during joint field expedition of the institutes of Far Eastern Branch of RAS (Vladivostok, Russia) and Institute of Oceanography (Nha Trang, Vietnam) on 23th - 25th May in 2007 using SCUBA diving. 85 samples were collected, encompassing the variety of species found on the reefs. The collection stations I, II and III belong to Dao Lon Island, the station IV belongs to Dao Be Island (table 1, fig. 1). All specimens were fixed in $4 \%$ formalin in the sea water, rinsed in the fresh water after $24 \mathrm{~h}$ and then transferred to $70 \%$ ethyl alcohol. Sclerites were obtained by dissolving the tissues in $10 \%$ sodium hypochlorite. The tissue samples of different colony parts (polyp, surface layer of the colony top, interior of the colony top, surface layer of the colony base and interior of the base) were examined separately through dissolving of the organic matter in sodium hypochlorite and observations under optical microscope with magnifications x 40, x 100 and x 400. The samples are identified basing on the literature such as Verseveldt (1980, 1982, 1983), Ofwegen (1987, 1991, 
1996, 2000, 2007, 2008), Tixier-Durivault (1956, 1958, 1970), Roxas (1930 I, 1930 II), Dautova (2009), Manuputty \& Ofwegen (2007), Grasshoff (1999, 2000, 2001), Vennam (1996), Utinomy (1954).

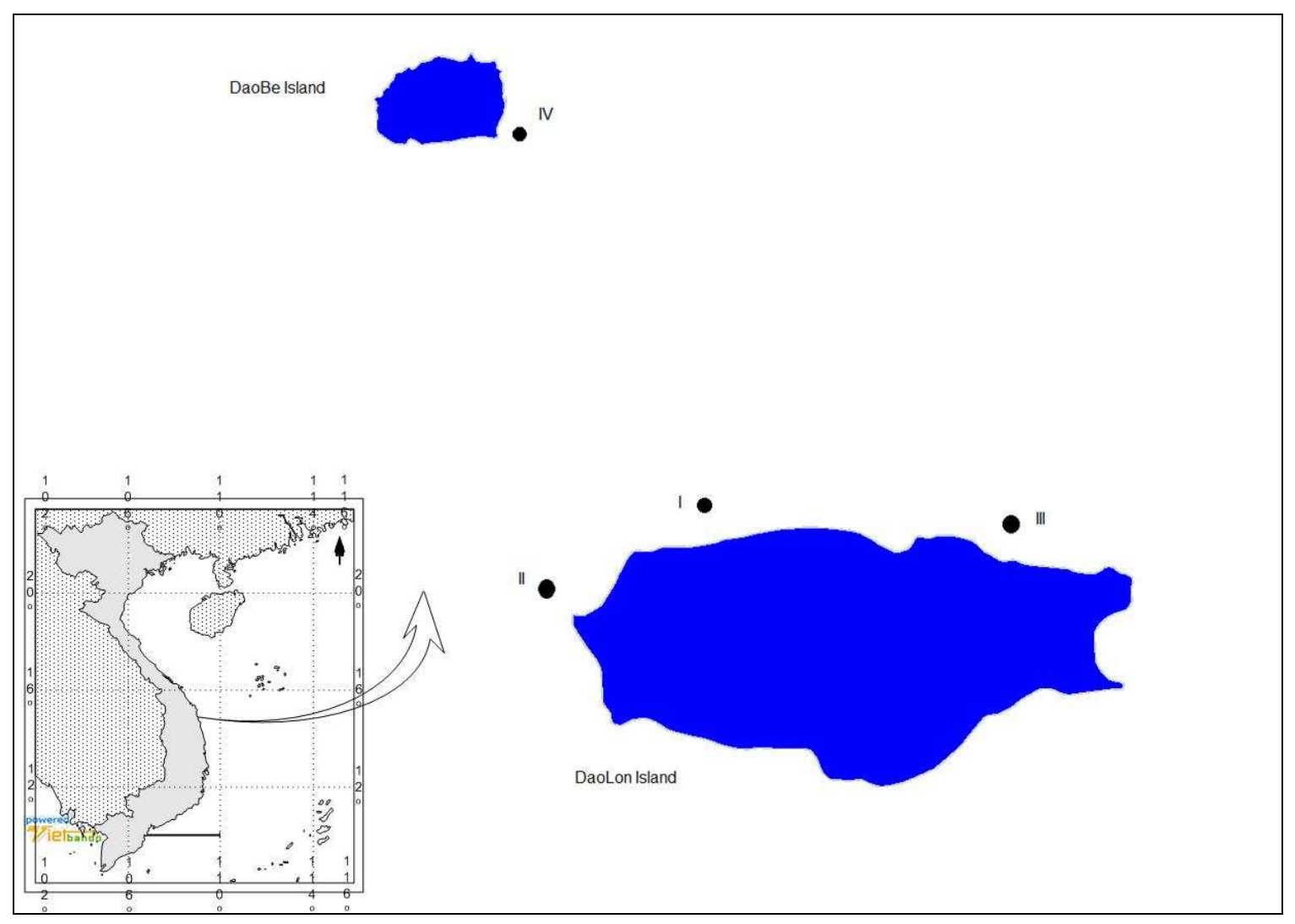

Figure 1: Sampling stations $(\bullet)$ in Ly Son islands.

\section{RESULTS}

\section{The composition and distribution of soft corals recorded in Ly Son islands}

The total 85 specimens were collected in Ly Son islands. The result of examinations is recorded with 60 taxa belonging to 10 genera and 5 families (see appendix I). The Sinularia genus is the most diverse with 24 species and Lobophytum 15 species and Sarcophyton 13 species. The eight specimens were identified only to genus level.

As it was displayed above, the Ly Son has separated two apart including Dao Lon and Dao Be islands. The 49 species recorded in Dao Lon Island meanwhile only 20 species recorded in Dao Be Island (table 2). The diversity of soft corals is the highest with 
23 species at the station II and the diversity is low with 10 species at the station III. Some species as Sinularia arctium, Sinularia cruciata, Lobophytum delectum, Sarcophyton birkelandi, Xenia umbellata were only recorded at each station.

Table 2: Amount of families, genera and species recorded in Ly Son islands

\begin{tabular}{|c|c|c|c|}
\hline Stations & Families & Genera & Species \\
\hline I & 4 & 5 & 21 \\
\hline II & 3 & 4 & 23 \\
\hline III & 3 & 6 & 10 \\
\hline IV & 1 & 4 & 20 \\
\hline Total & 5 & 8 & 60 \\
\hline
\end{tabular}

\section{The species firstly recorded in Vietnam}

Considering for the fauna of coral reefs in Ly Son, the composition of soft corals is firstly recorded in this area. Among the samples collected in Ly Son, two genera, such as Hicksonella and Briareum, and 33 species were firstly recorded in Vietnam while we compared our results with the authors who studied the taxonomy and fauna of soft corals in Vietnam as Tixier-Durivault (1970), Malyutin (1990), Dautova \& Savinkin (2009), Vo Si Tuan et al. (1994 \& 1997). Among the newly recorded species there were 14 Sinularia species, 9 Lobophytum species and 6 Sarcophyton species. Meanwhile some genera as Hicksonella, Paralemnalia, Nephthea, Xenia, Briareum have got one species each. The results showed that 26 species were determined in Dao Lon Island and 11 species in Dao Be Island. The number of species is the highest in the station II with 13 species and the lowest in the station III with 4 species (table 3).

As discussed above, the soft coral has been studied very few in Vietnam. The one of sufficient literature for taxonomy of soft coral in Vietnam is the Tixier-Durivault' publication (1970). She described 94 species of soft corals in Nha Trang bay, but we think that this literature is not enough reflecting completive biodiversity of soft coral in Vietnam. So that, our recorded result of the 60 species soft corals in Ly Son islands will contribute to biodiversity knowledge on coral reefs in Vietnam. The present collection shares 27 species with previous records by Tixier-Durivault (1970) and Dautova \& Savinkin (2009). On the other hand, the determination of 33 species and 2 genera as first records in Vietnam occupies more fifty percent of total species in Ly Son islands, and this 
result indicates not only the rich diversity but also the potential of taxonomy studies of soft coral not discovered yet in Vietnam.

Table 3: Amount of genera and species recorded firstly in Ly Son in Vietnam

\begin{tabular}{|c|c|c|}
\hline Stations & General & Species \\
\hline I & 1 & 11 \\
\hline II & & 13 \\
\hline III & 1 & 4 \\
\hline IV & & 11 \\
\hline Total & 2 & 33 \\
\hline
\end{tabular}

\section{CONCLUSION}

The biodiversity of soft coral has been firstly studied in Ly Son Islands with the composition of 60 taxa including 10 genera and 5 families recorded in Ly Son islands. The result showed that 49 species are recorded in the Dao Lon island, and 20 species were identified in the Dao Be island. Among the species were newly recorded in Vietnam, the Sinularia genus has 14 species, Lobophytum - 9 species, Sarcophyton - 6 species. Meanwhile, some genera - such as Hicksonella, Paralemnalia, Nephthea, Xenia, Briareum - have got one species each. This result showed that there are two genera Hicksonella, Briareum and 33 species firstly recorded and identified in Vietnam.

Acknowledgments: The field period of this study was funded totally by the joint project of the VAST and RAS institutes of 2007 S/V "Academician Oparin" scientific cruise. We would like to thank to the Institute of Oceanography and the Department of Marine Living Resources for the possibility and making good conditions for the first author to join to this expedition and to identify the collected specimens. We sent many thanks to Dr. Trinh The Hieu for his assistance in the collection of the samples during the expedition. The joint work on the species identification conducted in Nha Trang was supported financially for the trip of the Dr T. Dautova to ION Nha Trang by FEB RAS Foundation (Grant 09-III- A-06-195) and APN Grant ARCP2010-18NMY.

\section{REFERENCES}

1. Dautova, T. \& Savinkin O., 2009. New data on soft coral from Nha Trang Bay. Zootaxa 2027: 1-27. 
2. Fabricius K. \& Alderslade P., 2001. Soft coral and Sea fans. Australia Institute of Marine Science. Townsville. Australia. 264p.

3. Grasshoff M \& Bargibant. G, 2001. Coral reef Gorgonians of New Caledonia. Institut De Recherche Pour le Développement, Paris. 335pp.

4. Grasshoff M., 1999. Shallow water Gorgonians of New Caledonia and Adjacent islands (Coelenterata Octocorallia). Senckenbergiana biologica. Frankfurt am Main, $121 \mathrm{pp}$.

5. Grasshoff M, 2000. The Gorgonians of the Sinai coast and the Strait of Gubal, Red sea (Coelenterata Octocorallia). Courier Forschungsinstitut Senckenbergiana. Frankfurtam Main, 126pp.

6. Hickson S., 1919. Sur quelques specimen d'un Alcyonium d'Annam. Bull.Soc.Zool. France. Vol, XLIV

7. Malyutin, A.N., 1990. Two new species of Sinularia (Octocorallia: Alcyonacea) from South Vietnam. Asian Marine Biology, 7, 9-14.

8. Manuputty A.E.W \& Ofwegen L.P., 2007. The genus Sinularia (Octocorallia: Alcyonacea) from Ambon and Seram (Moluccas, Indonesia). Zool. Med. Leiden 81 (2007). 187-216.

9. Ofwegen L.P. van \& Vennam J., (1991) Notes on Octocorallia from the Laccadives (SW India). Zool Meded Leiden 65: 143-154.

10. Ofwegen, L.P. van, 1996. Octocorallia from the Bismark Sea (part II). Zoologische Mededelingen Leiden, 70, 207-215.

11. Ofwegen, L.P. van, 1987. Melithaeidae (Coelenterata: Anthozoa) from the Indian Ocean and the Malay Archipelago-Zool. Verh. Leiden 239: 3-57.

12. Ofwegen, L.P. van, 2002. Status of knowledge of the Indo Pacific soft coral genus Sinularia May, 1898 (Anthozoa: Octocorallia). Proceedings 9th International Coral Reef Symposium, Bali, 2000, 1: 167-171.

13. Ofwegen, L.P. van, 2008. The genus Sinularia (Octocorallia: Alcyonacea) from Bremer and West Woody islands (Gulf of Carpentaria, Australia). Zool. Med. Leiden 82 (16), 1.i.2008: 131-165.

14. Ofwegen, L.P. van, 2008. The genus Sinularia (Octocorallia: Alcyonacea) at Palau, Micronesia.Zool. Med. Leiden 82 (51), 31.xii.2008: 631-735. 
15. Roxas, H.A., 1933. Philippine Alcyonacea, I Families Cornularia and Xeniidae. The Philippine Journal of Science. Vol. 50 (1). 49-110.

16. Roxas, H.A., 1933. Philippine Alcyonacea, II Families Alcyoniidae and Nephthyidae.The Philippine Journal of Science. Vol. 50 (4). 345-483.

17. Stiasny G., 1938. Franzosisch Indochina Gesammelten Gogornarien. Mémori de Muséum National D’histoire Naturelle. Nouvelle série. Tom VI : Fascicule 3. 356368.

18. Tixier-Durivault, A., 1970. Les Octocoralliaires de Nha Trang (Vietnam). Cahiers du Pacifique 14 : 115-236.

19. Tixier-Durivault, A., 1956. Les Alcyonaires du Muséum. I. Famille des Alcyoniidae. 4. Genre Lobophytum. Bull. Mus.nat. Hist.nat. Paris, (2) 28 (4): 401-405.

20. Tixier-Durivault, A., 1958. Révision de la Famille des Alcyoniidae: les genres Sarcophyton et Lobophytum. Zool. Verhand., 36: 1-180.

21. Utinomy, H., 1954. Some Nephtheid Octocorals from Kii Coast Middle Japan , Publications of Seto Marine Biological Laboratory, Sirahama IV (1), 57-68.

22. Vennam, J. \& Ofwegen, L.P., 1996. Soft corals (Coelenterata: Octocorallia: Alcyonacea) from the Laccadives (SW India), with a re-examination of Sinularia gravis Tixier-Durivault, 1970. Zoologische Mededelingen Leiden, 48, 95-122.

23. Verseveldt J., 1980. A revision of the genus Sinularia May (Octocorallia: Alcyonacea). Zool. Verh. Leiden 179: 1-128.

24. Verseveldt J., 1982. A revision of the genus Sarcophyton Lesson (Octocorallia: Alcyonacea). Zool. Verh. Leiden 192: 1-91.

25. Verseveldt J., 1983. A revision of the genus Lobophytum von Marenzeller (Octocorallia: Alcyonacea). Zool. Verh.Leiden 200: 1-103.

26. Vo Si Tuan, Nguyen Huy Yet, Alino P.M., 1997. Coral and coral reef in the north of Spratly Archipelago - The results of RP-VN JOMSRE-SCS 1996. Proceeding of scientific conference on RP-VN JOMSRE-SCS 1996. Hanoi 22 - 23 April 1997. 87-101.

27. WWF Vietnam Marine Conservation Southern Survey Team, 1994. Survey report on the Biodiversity, Resource Utilization and Conservation Potential of Cat Ba, Hon Mun, Cu Lao Cau, An Thoi, Co To, Con Dao. Institute of Oceanography (Nha Trang, Hai phong, Vietnam) and WWF. Unpublished report, 95p. 
THE LIST OF THE SOFT CORAL SPECIES AT THE STATIONS IN LY SON ISLANDS

\begin{tabular}{|c|c|c|c|c|c|c|c|}
\hline \multirow[t]{2}{*}{ No } & \multirow[t]{2}{*}{ Genera } & \multirow[t]{2}{*}{ Species } & \multicolumn{4}{|c|}{ Stations } & \multirow{2}{*}{$\begin{array}{l}\text { New } \\
\text { record }\end{array}$} \\
\hline & & & 1 & 2 & 3 & 4 & \\
\hline 1. & $\begin{array}{l}\text { Sinularia } \\
\text { May, } 1898\end{array}$ & $\begin{array}{c}\text { Sinularia abhishiktae Ofwegen \& } \\
\text { Vennam, } 1991\end{array}$ & + & + & & & + \\
\hline 2. & & $\begin{array}{l}\text { S. arctium Dautova \& Savinkin, } \\
2009\end{array}$ & + & & & & \\
\hline 3. & & S. capillosa Tixier-Durivault, 1970 & + & + & & & \\
\hline 4. & & S. ceramensis Verseveldt, 1977 & & + & & & + \\
\hline 5. & & $\begin{array}{c}\text { S. corpulentissima Manuputty \& van } \\
\text { Ofwegen, } 2007\end{array}$ & + & & & & + \\
\hline 6. & & S. compacta Tixier-Durivault, 1970 & & & & + & + \\
\hline 7. & & S. conferta (Dana,1846) & & + & & & + \\
\hline 8. & & S. cristata Tixier-Durivault, 1969 & & & & + & + \\
\hline 9. & & S. cruciata Tixier-Durivault, 1970 & + & & & & \\
\hline 10. & & S. densa (Whitelegge, 1897) & & & & + & \\
\hline 11. & & S. erecta Tixier-Durivault, 1945 & & & & + & + \\
\hline 12. & & S. facile Tixier-Durivault, 1970 & & & & + & \\
\hline 13. & & S. fishelsoni Verseveldt, 1970 & & & + & & + \\
\hline 14. & & S. flexuosa Tixier-Durivault, 1945 & + & & & & + \\
\hline 15. & & S. granosa Tixier-Durivault, 1970 & & & & + & \\
\hline 16. & & S. inexplicita Tixier-Durivault, 1970 & + & & & & \\
\hline 17. & & S. minima Verseveldt, 1971 & & + & & & + \\
\hline 18. & & S. mollis Kolonko, 1926 & & + & & & + \\
\hline 19. & & S. nanolobata Verseveldt, 1977 & + & & & & + \\
\hline 20. & & S. numerosa Tixiter- Durivault, 1970 & & + & & & + \\
\hline 21. & & S. parva Tixier-Durivault, 1970 & & + & & & \\
\hline 22. & & S. polydactyla (Ehrenberg, 1834) & & + & & & \\
\hline 23. & & S. querciformis (Pratt, 1903) & & + & & & \\
\hline 24. & & S. brassica May, 1898 & + & & & & + \\
\hline
\end{tabular}




\begin{tabular}{|c|c|c|c|c|c|c|c|}
\hline \multirow[t]{2}{*}{ No } & \multirow[t]{2}{*}{ Genera } & \multirow[t]{2}{*}{ Species } & \multicolumn{4}{|c|}{ Stations } & \multirow{2}{*}{$\begin{array}{l}\text { New } \\
\text { record }\end{array}$} \\
\hline & & & 1 & 2 & 3 & 4 & \\
\hline 25. & $\begin{array}{c}\text { Lobophytum } \\
\text { Marenzeller, } \\
1886\end{array}$ & Lobophytum batarum Moser, 1919 & + & + & + & & \\
\hline 26. & & $\begin{array}{l}\text { L. compactum Tixier-Durivault, } \\
1956\end{array}$ & & + & & + & \\
\hline 27. & & L. crassum Von Marenzeller, 1886 & & + & & + & + \\
\hline 28. & & L. delectum Tixier-Durivault, 1966 & & + & & & + \\
\hline 29. & & L. jaeckeli Tixier-Durivault, 1956 & & + & & & + \\
\hline 30. & & L. lighti Moser, 1919 & & & & + & + \\
\hline 31. & & L. pauciflorum (Ehrenberg, 1834) & + & & + & + & \\
\hline 32. & & L. salvati, Tixier-Durivault, 1970 & & & & + & + \\
\hline 33. & & L. sarcophytoides Moser, 1919 & + & & & & + \\
\hline 34. & & L. schoedei Moser, 1919 & & & & + & + \\
\hline 35. & & L. variatum Tixier-Durivault, 1957 & & & & + & + \\
\hline 36. & & L. varium Tixier Durivault, 1970 & & & & + & + \\
\hline 37. & & Lobophytum sp 1 & & + & & & \\
\hline 38. & & Lobophytum sp 2 & & & & + & \\
\hline 39. & & Lobophytum sp 3 & & & & + & \\
\hline 40. & $\begin{array}{l}\text { Sarcophyton } \\
\text { Lesson, } 1834\end{array}$ & $\begin{array}{l}\text { S. boletiforme Tixier-Durivault, } \\
1958\end{array}$ & & + & & + & + \\
\hline 41. & & $\begin{array}{l}\text { S. tenuispiculatum Thomson \& } \\
\text { Dean, } 1931\end{array}$ & + & & & & + \\
\hline 42. & & $\begin{array}{c}\text { S. ehrenbergi Von Marenzeller, } \\
1886\end{array}$ & + & & & & \\
\hline 43. & & S. solidum Tixier-Durivault, 1958 & + & & & & + \\
\hline 44. & & S. birkelandi Verseveldt, 1978 & & + & & & + \\
\hline 45. & & $\begin{array}{l}\text { S. cherbonnieri, Tixier-Durivault, } \\
1958\end{array}$ & + & & & + & + \\
\hline 46. & & S. cinereum Tixier-Durivault, 1946 & & & + & & \\
\hline 47. & & S. ehrenbergi Von Marenzeller, & & & + & & \\
\hline
\end{tabular}




\begin{tabular}{|c|c|c|c|c|c|c|c|}
\hline \multirow[t]{2}{*}{ No } & \multirow[t]{2}{*}{ Genera } & \multirow[t]{2}{*}{ Species } & \multicolumn{4}{|c|}{ Stations } & \multirow{2}{*}{$\begin{array}{l}\text { New } \\
\text { record }\end{array}$} \\
\hline & & & 1 & 2 & 3 & 4 & \\
\hline & & 1886 & & & & & \\
\hline 48. & & S. elegans Moser, 1919 & & + & & & \\
\hline 49. & & $\begin{array}{l}\text { S. glaucum (Quoy \& Gainmard, } \\
\text { 1833) }\end{array}$ & + & & & + & \\
\hline 50. & & $\begin{array}{l}\text { S. pulchellum (Tixier-Durivault, } \\
\text { 1957) }\end{array}$ & & + & & & + \\
\hline 51. & & S. serenei Tixier-Durivault, 1958 & & + & & & \\
\hline 52. & & Sarcophyton $s p$ & & & + & & \\
\hline 53. & $\begin{array}{l}\text { Cladiella } \\
\text { Gray, } 1869\end{array}$ & Cladiella $s p$ & & & + & & \\
\hline 54. & $\begin{array}{c}\text { Xenia } \\
\text { Lamarck, } \\
1816\end{array}$ & Xenia umbellata Lamarck, 1816 & & + & & & + \\
\hline 55. & $\begin{array}{c}\text { Tubipora } \\
\text { Linnaeus, } \\
1758\end{array}$ & Tubipora musica Linnaeus, 1758 & + & & & & \\
\hline 56. & $\begin{array}{l}\text { *Hicksonella } \\
\text { Nutting, } 1910\end{array}$ & Hicksonella princeps Nutting, 1910 & + & & & & + \\
\hline 57. & $\begin{array}{c}\text { Paralemnalia } \\
\text { Kukenthal, } \\
1913\end{array}$ & $\begin{array}{l}\text { Paralemnalia eburnea Kukenthal, } \\
1913\end{array}$ & + & & + & & + \\
\hline 58. & $\begin{array}{c}\text { Nephthea } \\
\text { Audouin, } \\
1826\end{array}$ & Nephthea brassica Kukenthal, 1903 & & & + & & + \\
\hline 59. & & Nephthea sp & + & + & & + & \\
\hline 60. & $\begin{array}{c}\text { *Briareum } \\
\text { Blainville, } \\
1830\end{array}$ & Briareum sp & & & + & & \\
\hline & & Total & 21 & 23 & 10 & 20 & 33 \\
\hline
\end{tabular}

*The genus is newly recorded in Vietnam 


\title{
SAN HÔ MỀM (OCTOCORALLIA: ALCYONACEA) Ở ĐẢO LÝ SƠN, MIỀN TRUNG VIẸTT NAM
}

\author{
HOÀNG XUÂN BỀn, TATYANA N. DAUTOVA
}

Tóm tắt: Lý Son là huyện đảo thuộc tỉnh Quảng Ngãi cách đất liền $20 \mathrm{~km}$, bao gồm hai đảo là Đảo Lón và Đảo Bé. Điều kiện môi truòng ở đây được xem là khác biệt so với vùng nuoóc ven bò̀ nơ mà môi truờng nước không trong nhung khá tĩnh lặng. Mặt khác, nhũng vùng rạn xa bò̀ nhu Lý Sơn càng có ít các nghiên cưu về đa dạng sinh học trong hệ sinh thái rạn san hô. Trong số 85 mẫu thu thập đã xác định được 60 taxa thuộc 10 giống và 5 ho san hô mềm. So với các nghiên cúu trước đây ở vùng biển Việt Nam, kết quả phân tích đã xác định được 2 giống và 33 loài mói ghi nhận lần đầu cho vùng biển ven bò̀ Việt Nam. Trong đó giống Sinularia có số loài mới nhiều nhất là 14 loài, tiếp đến là Lobophytum 9 loài, Sarcophyton 6 loài. Bốn giống còn lại là Hicksonella, Paralemnalia, Nephthea, Xenia mỗi giống có một loài mói ghi nhận lần đầu tiên cho vùng biển Việt Nam.

Ngày nhận bài: 14 - 06 - 2009

Nguò̀i nhận xét: TS. Võ Sĩ Tuấn 